\title{
REFERENCES
}

Bauer K., 1960: Die Säugetiere des Neusiedlersee-Gebietes. Bonn. zool. Beitr., 11: 141-344. - Fedyk S. \& Borowski S., 1980: Colour variates in the Białowieża population of European water shrew. Acta theriol., 25: 3-24. - Kahmann H. \& Rössner F. X., 1956: Die Natur der Färbungsvielgestaltigkeit der Unterseide bei der Wasserspitzmaus (Neomys). Naturwissenschaften, 43: 46. - Laar E. \& Daan N., 1976: Neomys anomalus Cabrera, 1907, observé dans les Ardennes francaises. Lutra, 18: 44-51. - Michalak I., 1983: Colour patterns in Neomys anomalus. Acta theriol., 28: 25-32. - Spitzenberger F., 1980: Sumpf- und Wasserspitzmaus (Neomys anomalus Cabrera 1907 and Neomys fodiens Pennant 1771) in Osterreich. Mitt. Abt. Zool., 9: 1-39.

Accepted, September 13, 1985

\section{On the Assessment of Trapping Success}

SZACOWANIE EFEKTYWNOSCI ODEOWOW

\author{
Javier A. SIMONETTI
}

Simonetti J. A., 1986: On the assessment of trapping success. Acta theriol., 31, 14: 171-175 [With 1 Table]

Frequency of captures of small mammals are often expressed as trapping success. Three different methods for calculating trapping success are empirically validated. It is shown that different conclusions could be drawn about frequency of captures depending upon the method employed.

[College of Forest Resources AR-10, University of Washington, Seattle, WA 98195 , U.S.A.]

Microhabitat use by small mammals has been traditionally studied through trapping, in such a way that differential rates of captures at given trap locations are interpreted as an index of microhabitat use (Price, 1977). The results are often expressed as animals per trap-night (sensu. Grinnell, 1914). When using this index, it must be considered the decrease in trapping efficiency resulting from traps removed from the overall catching effort. This concept is known as gear saturation, and states that as the gear (i.e. traps) become full - less are available for future captures $\rightarrow$ its efficiency decreases. The reduction in trapping efficiency implies that catch-per-unit-effort or trapping success does not necessarily represent the relative abundance of the organisms being sampled (Kennedy, 1951).

Traps for small mammals are removed from the overall catching effort when they are sprung either by the species under study or other non-target species, as well as when they are accidentally sprung due to mechanical failure of the spring mechanism. Traps from which bait 
is or has been removed by ants should also be considered removed from the catching effort, as bait is necessary to obtain reliable trapping efficiencies (Patrick, 1970).

Nelson \& Clark (1973) have proposed a method to correct trapping success estimates. Basically, the traditional equation for trapping success calculations (e.g. DeBlase \& Martin, 1974)

$$
T S_{1}=A \times 100 / T U
$$

was modified to

$$
T S_{2}=A \times 100 /(T U-I S / 2),
$$

where TS is trapping success expressed as animals captured per 100 trapping units, $A$ is the number of small mammals caught, $T U$ is the number of trapping units in that

$$
T U=P \times I \times N,
$$

being $P$ the number of trapping intervals (usually one night), $I$ the lenght of the trapping interval, $N$ the number of traps being used and, IS the number of sprung traps by all causes.

It has been shown, through an hypothetical trapping experiment, that significant errors arise in calculating trapping efficiencies if there is no adjustment for trap saturation, obscuring comparisons within and between populations (Nelson \& Clark, 1973). So far, the corrected $\mathrm{TS}_{2}$ equation had not been empirically validated using field gathered data. Such a test is performed here, showing that both the traditional $\left(\mathrm{TS}_{1}\right)$ and improved $\left(\mathrm{TS}_{2}\right)$ methods give unreliable results when compared to a third and simpler method proposed here.

The third method $\left(\mathrm{TS}_{3}\right)$ simply consists in calculating trapping success based on the actual number of traps available for the small mammals being studied. In order to do so, the number of sprung traps either by trap-misfunction or by nontarget species (i.e. lizards, small birds) as well as the number of traps being used by ants while removing bait and the number of traps without bait already are counted when servicing the traps, the total being discounted to the number of traps set in the study grid. This value is then added as a new variable to the calendar of catches (see Petrusewicz \& Andrzejewski, 1962). The corresponding equation is

$$
T S_{3}=A \times 100 /(T U-N A),
$$

where $N A$ is the number of unavailable number of traps for the small mammals as described above. 
Data used here to validate trapping success estimates were gathered when live-trapping nocturnal small mammals in a shrubland area of Los Dominicos, $20 \mathrm{~km}$ E Santiago, Central Chile. Small mammals were studied during the winter and spring (hereafter winter; August to November) 1984 for 39 nights and the summer (January) 1985 for 10 nights. The trapping grid consisted of 50 large Sherman traps arrayed in a 5 by 10 fashion, $10 \mathrm{~m}$ apart. Traps were baited daily with oatmeal and serviced during early morning (details will be published elsewhere).

The traditional $\left(\mathrm{TS}_{1}\right)$ way of calculating trapping success yielded the lowest estimates during both winter and summer seasons. The method $\left(\mathrm{TS}_{3}\right)$ proposed here gave the highest while Nelson \& Clark (1973) $\left(\mathrm{TS}_{2}\right)$ equation rendered intermediate trapping success estimates. During the winter, trapping success estimates were similar but still significantly different (Table 1). Differences ranged from as low as $1.3 \%$ between

Table 1

Trapping success estimates using different methods.

\begin{tabular}{|c|c|c|c|c|}
\hline & $\underset{\text { (TS1) }}{\text { Traditional }}$ & $\begin{array}{l}\text { Nhods } \\
\text { Nelson \& Clark } \\
\text { (TS2) }\end{array}$ & (TS3) & $P^{1}$ \\
\hline $\begin{array}{l}\text { Winter } \\
\text { Summer } \\
p^{2}\end{array}$ & $\begin{array}{l}7.0 \pm 1.1 \\
6.6 \pm 3.2 \\
p>0.20\end{array}$ & $\begin{array}{l}7.9 \pm 1.3 \\
10.9 \pm 1.3 \\
p>0.20\end{array}$ & $\begin{array}{r}8.3 \pm 1.2 \\
21.6 \pm 9.8 \\
p<0.002\end{array}$ & $\begin{array}{l}p<0.001 \text { all comparisons } \\
p<0.001 \text { all comparisons }\end{array}$ \\
\hline
\end{tabular}

1 Wilcoxon paired-sample, two tailed test, ${ }^{2}$ Mann-Whitney, two tailed $U$ test.

$\mathrm{TS}_{2}$ and $\mathrm{TS}_{3}$ to as high as $14.3 \%$ between $\mathrm{TS}_{1}$ and $\mathrm{TS}_{3}$. During the summer however, trapping success estimates were clearly and significantly different (Table 1). Differences between estimates ranged from as low as $65.2 \%$ between $\mathrm{TS}_{1}$ and $\mathrm{TS}_{2}$ to as high as $227.3 \%$ between $\mathrm{TS}_{1}$ and $\mathrm{TS}_{3}$.

The three methods for calculating trapping success differed in their power to detect seasonal differences. The traditional $\mathrm{TS}_{1}$ pointed to a lower but statistically non significant different trapping success during the summer (Table 1). The opposite was true for Nelson \& Clark (1973) $\mathrm{TS}_{2}$ and the $\mathrm{TS}_{3}$ method. Both $\mathrm{TS}_{2}$ and $\mathrm{TS}_{3}$ pointed to a higher trapping success during the summer when compared to winter estimates. Only $\mathrm{TS}_{3}$, however detected statistically significant differences between seasons (Table 1).

Different conclusions could have been drawn from the same data set depending upon the method employed for calculating trapping success. While the winter estimates were similar, summer ones were 
clearly not so. Differences are largely due to the assumtions of each method. The traditional method $\left(\mathrm{TS}_{1}\right)$ assumes that all traps are available for the target species. In the present case, every night each one of the 50 traps could have been used by and therefore capture a small mammal. This assumption is empirically falsified as on the average, $2.0 \pm 0.8$ and $10.1 \pm 7.9$ traps were accidentaly sprung each night during the winter and summer seasons, respectively. The difference between them is statistically significant (Mann-Whiney two tailed $U$ test, $p<0.001$ ). In addition, lizards and birds were also captured by the traps intended for small mammals. Lizards and birds were captured more frequently during the summer than the winter season ( 38 versus 16 eases, respectively. Chi-square with Yates correction for continuity $\neq 13.7,(P<0.001)$. Similarly, bait was removed from the traps by ants, being this phenomenon more common during the summer than the winter $(27.6 \pm 3.8 n=10$ nights versus $6.1 \pm 1.8 n=$ nights, respectively. Mann-Whitney two-tailed $U$ test, $P<0.001$ ). As long as traps are sprung by factors other than the target species, the traditional $\mathrm{TS}_{\mathbf{1}}$ method will give lower than actual trapping success values.

Nelson \& Clark (1973) (TS 2 ) method assumes that "on the average, each trap is sprung for half the trapping interval [and that] this assumption can be met experimentally by adjusting the middle of the trapping interval to coincide with the peak of activity of the animals been sought" (Nelson \& Clark, 1973: 296). This assumption is somewhat unrealistic for the study of multispecies systems such as an assemblage of small mammals. Different syntopic species of small mammals may exhibit peaks of activity at different times during the trapping interval (i.e. night; see for example Murúa et al., 1982). The peak of activity of other springing factors may also be allochronic regarding that of the target species. Nelson \& Clark (1973) pointed out that the errors in trapping success estimates vary with the number of target specimens captured and the number of traps sprung by other factors, being these errors additive. The $\mathrm{TS}_{2}$ equation is also sensitive to these factors. While the numbers of nocturnal small mammals captured during the winter and summer seasons did not varied significantly in the present study $(3.5 \pm 0.5$ versus $3.3 \pm 0.6$ animals/night, respectively. Mann-Whitney two-tailed $U$ test, $P<0.20$, the other factors did as already shown. The increased number of unavailable traps was unaccurately accounted for the $\mathrm{TS}_{2}$ equation, rendering lower than actual estimates.

The method proposed here has no assumptions regarding the number of available traps. On the contrary, it is based on the actual gear saturation, as the number of sprung or otherwise unavailable traps are recorded daily. In this regard, $\mathrm{TS}_{3}$ is more realistic and precise than 
previous methods for calculating trapping success, and does not require additional field work other than the usual one when servicing the traps.

An accurate trapping success estimate is required for comparisons of microhabitat use between species or seasons. As shown, depending on the method choosen, actual differences can be obscured by unreliable estimates. The method proposed here seems to be more accurate than the previous ones being used, and should be preferred when studying microhabitat use by small mammals.

Acknowledgements: The support from Sigma-Xi (Grant-in-Aid of Research) and an Agnes Healy Anderson Fellowship, College of Forest Resources, University of Washington is acknowledged with gratitude,

\section{REFERENCES}

DeBlase A. F. \& Martin R. E., 1974: A manual of mammalogy, with keys to the families of the world. 1-320, Brown Co. Publ., Iowa. - Grinnell, J., 1914: A survey of the mammals of the lower Colorado Valley. Univ. California Publ. Zool., 12: 1-92. - Kennedy W. A., 1951: The relationship of fishing effort by gill nets to the interval between lifts: J. Fish. Res: Bd. Canada 8: 264-274. Murúa R., Gonzales L. \& Jofre C., 1982: Estudios ecológicos de roedores silvestres en los bosques templados fríos de Chile. Publ. Ocas,, Mus. Nac. Hist. Nat. (Chile) 38: 105-116. - Nelson L. Jr. \& Clark F. W., 1973: Correction for sprung traps in catch/effort calculations of trapping results. J. Mamm., 54: 295-298. — Patrick E. F., 1970: Bait preference of small mammals. J. Mamm, 51: 179-182. - Petrusewicz K. \& Andrzejewski R., 1962:-Natural history of free living population of house mice (Mus musculus Linnaeus), with particular reference to groupings within the populations. Ekol. pol., A 10: 85-122. - Price M. V. 1977: Validity of live trapping as a measure of foraging activity of heteromyid rodents. J. Mamm., 58: $107-110$.

Accepted, July 3, 1985. 